\title{
The effect of Charolais and Hereford sires and straightbred and crossbred dams on pre-weaning growth of calves
}

\author{
H. Dadi ${ }^{1}$, G.F. Jordaan ${ }^{1}$, S.J. Schoeman ${ }^{1 \#}$ and J. van der Westhuizen ${ }^{2}$ \\ ${ }^{1}$ Department of Animal Sciences, University of Stellenbosch, Private Bag X1, Matieland, Stellenbosch 7602, \\ South Africa \\ ${ }^{2}$ ARC-Animal Improvement Institute, Private Bag X2, Irene 0062, South Africa
}

\begin{abstract}
Weaning performance of calves sired by Charolais and Hereford on dams of Angus, Bonsmara and Hereford and various crossbred dam combinations was compared. Charolais sired calves were on average 5 $\mathrm{kg}$ heavier at birth and $20 \mathrm{~kg}$ heavier at weaning than Hereford sired calves. Among the three straightbred dam breeds, the Bonsmara weaned calves that were approximately $6 \%$ heavier than both the Angus and the Hereford calves. The use of crossbred dams having intermediate levels of Charolais composition is suggested in crossbreeding programmes in intensive production systems based on cultivated pastures under irrigation.
\end{abstract}

Keywords: beef cattle, crossbreeding, pre-weaning growth

\#Corresponding author. E-mail: sjsc@maties.sun.ac.za

\section{Introduction}

Crossbreeding has been proposed as a means to improve production under different environmental conditions. This practice has become widely accepted in commercial cattle. (Harwin, 1989). It involves the combining of two or more breeds selected for their economic benefits to optimise simultaneously the use of both non-additive (heterosis) and additive (breed difference) effects. The effective exploitation of these effects requires an evaluation and understanding of beef cattle breeds to be used for crossbreeding systems. The important question regarding commercial beef production is not whether or not crossbreeding should be employed, but rather what breeds should be used in different crossbreeding systems in different feed and production situations (Long, 1980; Harwin, 1989; Bourdon, 2000).

Evaluation of factors influencing economically important traits in a diversity of environmental conditions is important to design well-planned crossbreeding systems aimed at maximising productivity of the herd. The type of both sire and dam breed clearly determines the performance of their progeny, although the environment is also very important. Limited information is, furthermore, available on the use of the Bonsmara in crossbreeding operations. Performances of individual breeds or breed combinations are not expected to be the same under all environments. Therefore, breeds and crossbred combinations should be evaluated under a variety of environmental conditions. The objective of this investigation was to evaluate the production performance of different breeds and breed crosses in an intensive production system based on cultivated pastures under irrigation.

\section{Materials and Methods}

Birth weight $(\mathrm{BW})(\mathrm{n}=2535)$ and weaning weight $(\mathrm{WW})$ records $(\mathrm{n}=2535)$ were collected from calves born between 1968 and 1982 from straightbred and various two- and three-breed terminal and rotational crossbreeding systems which involved Angus (A), Hereford (H), Bonsmara (B) and Charolais (C) breeds. The cattle were located at the two farms of the Johannesburg Metropolitan Council. Breeding systems, herd management, recording and selection procedures were described by Paterson et al. (1980), Schoeman \& Jordaan (1999) and Skrypzeck et al. (2000a; b).

Hereford and Charolais sires were mated to straightbred and crossbred dams. All sires were used on both farms to artificially inseminate the females. The number of sires used was 40 (28 Charolais and 12 Hereford) with an average of 63.4 calves per sire.

The dam genotypes used in the analysis included Angus (A), Hereford (H), Bonsmara (B), two-breed crosses of equal proportions, Angus x Charolais (AC), Hereford x Angus (HA), Charolais x Bonsmara (CB), Hereford x Bonsmara (HB), Hereford x Charolais (HC), backcross cows of Hereford x Angus (HA), Hereford $x$ Charolais (HC) and three-breed crosses of Charolais x (Angus x Hereford) (CAH). Twelve dam 
genotypes (three purebred and nine crossbred) were available. Dam ages ranged from 2 to 17 years. They were categorized into four age groups, viz. heifers calving for the first time at 2 years, 3 year old cows, mature cows ( 4 to 8 years) and old cows (9 plus years). The average age of the dams was 6.8 years. The number of dams used was 1162 with an average of 2.20 calves per dam. Heifers were first inseminated to calve for the first time at approximately two years of age. The farms purchased a large percentage of the base cows, and data were not adequately recorded to allow for the identification of reciprocal crosses among some of the crossbred cows.

About $70 \%$ of the calves was born from June to October, while the balance was born from November to May. Season of birth was thus recorded as 'winter born' or 'summer born'. Number of calves represented in each breed of sire and breed genotypes of dam combination is illustrated in Table 1.

Table 1 Number of observations by breed of sire and dam for birth weight and weaning weight of calves

\begin{tabular}{lccc}
\hline \multirow{2}{*}{ Dam genotype } & \multicolumn{3}{c}{ Sire breed } \\
\cline { 2 - 4 } & Charolais $(\mathrm{C})$ & Hereford $(\mathrm{H})$ & Total \\
\hline Angus (A) & 236 & 155 & 391 \\
Bonsmara (B) & 187 & 108 & 295 \\
Hereford (H) & 136 & 452 & 588 \\
$1 / 2 \mathrm{~A}^{1 / 2 \mathrm{C}}$ & 114 & 27 & 141 \\
$1 / 2 \mathrm{H}^{1} / 2 \mathrm{~A}$ & 355 & 259 & 614 \\
$1 / 2 \mathrm{C}^{1 / 2 \mathrm{~B}}$ & 40 & 5 & 45 \\
$1 / 2 \mathrm{H}^{1} / 2 \mathrm{~B}$ & 25 & 29 & 54 \\
$1 / 2 \mathrm{H}^{1} / 2 \mathrm{C}$ & 87 & 14 & 101 \\
$1 / 2 \mathrm{C}^{1} / 4 \mathrm{~A} 1 / 4 \mathrm{H}$ & 159 & 16 & 175 \\
$3 / 4 \mathrm{C}^{1} / 8 \mathrm{~A} 1 / 8 \mathrm{H}$ & 8 & 41 & 49 \\
$3 / 4 \mathrm{H}^{1} / 4 \mathrm{~A}$ & 5 & 50 & 55 \\
$3 / 4 \mathrm{H}^{1 / 4 \mathrm{C}}$ & 13 & 14 & 27 \\
\hline Total & 1365 & 1170 & 2535 \\
\hline
\end{tabular}

Data were analysed using General Linear Model (GLM) procedures of SAS (1996). Owing to the absence of certain reciprocal and backcrosses, the data was unsuitable for the estimation of breed specific direct and maternal and dominance effects using conventional procedures (Dillard et al, 1980; Schoeman et $a l, 1993)$. The model included the fixed effects of breed of sire, breed genotype of dam, sex of calf, herdyear-season and dam age. First order interactions having no effect $(\mathrm{P}>0.05)$ were omitted from the final model as well as the interactions $(\mathrm{P}<0.05)$ sire breed $\mathrm{x}$ HYS for BW and dam genotype $\mathrm{x}$ HYS for WW because the model was overspecified and unable to estimate least squares means thereof.

The final reduced model was as follow:

$\begin{array}{ll}\mathrm{Y}_{\mathrm{ijklm}} & =\mu+\mathrm{S}_{\mathrm{i}}+\mathrm{D}_{\mathrm{j}}+\mathrm{X}_{\mathrm{k}}+\mathrm{H}_{1}+\mathrm{A}_{\mathrm{m}}+\mathrm{e}_{\mathrm{ijk} k \mathrm{~m}} \text {, where } \\ \mathrm{Y}_{\mathrm{ijk} k \mathrm{~m}} & =\text { the value of the appropriate trait }(\mathrm{BW}, \mathrm{WW}) \text { under consideration } \\ \mu & =\text { population mean for the appropriate trait } \\ \mathrm{S}_{\mathrm{i}} & =\text { effect of the } \mathrm{i}^{\text {th }} \text { breed of sire }(\mathrm{n}=2) \\ \mathrm{D}_{\mathrm{j}} & =\text { effect of the } \mathrm{j}^{\text {th }} \text { breed genotype of dam }(\mathrm{n}=12) \\ \mathrm{X}_{\mathrm{k}} & =\text { effect of the } \mathrm{k}^{\text {th }} \text { sex of calf }(\mathrm{n}=2) \\ \mathrm{H}_{1} & =\text { effect of the } \mathrm{l}^{\text {th }} \text { herd-year-season }(\mathrm{n}=53) \\ \mathrm{A}_{\mathrm{m}} & =\text { effect of the } \mathrm{m}^{\text {th }} \text { age of dam }(\mathrm{n}=4) \\ \mathrm{E}_{\mathrm{ijklm}} & =\text { random residual effects }\end{array}$

For WW, weaning age of calf was included as a covariate.

\section{Results and Discussion}

An analysis of variance for BW and WW are presented in Table 2. The fixed effects of herd-yearseason, sex of calf and age of dam all had an influence $(\mathrm{P}<0.001)$ on both $\mathrm{BW}$ and $\mathrm{WW}$. Weaning age of 
calves was also important for WW $(\mathrm{P}<0.001)$. Least squares means for $\mathrm{BW}$ and $\mathrm{WW}$ by breed of sire are presented in Table 3.

Table 2 Analysis of variance for birth weight (BW) and weaning weight (WW) of calves

\begin{tabular}{lcrr}
\hline Source of variation & & \multicolumn{2}{c}{ F values } \\
\cline { 3 - 4 } & df & Birth weight $(\mathrm{kg})$ & Weaning weight $(\mathrm{kg})$ \\
\hline Breed of sire & 1 & $368.2^{*}$ & $231.9^{*}$ \\
Dam genotype & 11 & $12.5^{*}$ & $12.8^{*}$ \\
Sex of calf & 1 & $197.8^{*}$ & $237.0^{*}$ \\
Age of dam & 3 & $19.0^{*}$ & $18.9^{*}$ \\
Herd-year-season & 52 & $5.2^{*}$ & $11.9^{*}$ \\
Weaning age of calves & 1 & & $129.1^{*}$ \\
Mean $( \pm$ s.d.) & & $35.5( \pm 4.6)$ & $191.2( \pm 23.7)$ \\
$\mathrm{R}^{2}$ model $(\%)$ & & 45.9 & 56.1 \\
\hline$* \mathrm{P}<0.001$ & & &
\end{tabular}

Table 3 Least squares means and standard errors for birth weight (BW) and weaning weight (WW) of calves by breed of sire

\begin{tabular}{|c|c|c|c|}
\hline Breed of sire & $\mathrm{N}$ & BW $(\mathrm{kg}) \pm$ s.e. & $\mathrm{WW}(\mathrm{kg}) \pm$ s.e. \\
\hline Charolais & 1365 & $38.4 \pm 0.26^{\mathrm{a}}$ & $197.1 \pm 1.3^{\mathrm{a}}$ \\
\hline Hereford & 1170 & $33.4 \pm 0.27^{b}$ & $177.5 \pm 1.4^{\mathrm{b}}$ \\
\hline Mean & & $35.9 \pm 0.27$ & $187.3 \pm 1.3$ \\
\hline
\end{tabular}

Breed of sire had an effect on both BW and WW $(\mathrm{P} \leq 0.001)$. At birth the Charolais sired calves were on average $5 \mathrm{~kg}$ heavier than the Hereford sired calves and approximately $20 \mathrm{~kg}$ (or 11\%) heavier at weaning. Pahnish et al. (1969) also found that Charolais sired calves were $19.3 \mathrm{~kg}$ heavier at weaning than Hereford sired calves.

The Charolais is known to sire calves of high birth weights. The incidence of dystocia in Charolais sired calves due to high BW has been well recognized by a number of authors (Laster et al., 1973; Smith et al., 1976). Pahnish et al. (1969) reported that the Charolais as breed of sire produced heavier calves at birth than the Charolais as breed of dam. Large positive direct effects compared to small positive or even negative maternal effects which were also reported elsewhere, supported this view (Newman et al., 1993; Franke et al., 2001). For Hereford, the direct additive effect for BW was positive in some reports (Gregory et al., 1978; Schoeman et al., 1993), but negative in other crossbreeding studies (Alenda et al., 1980; Skrypzeck et al., 2000a). Skrypzeck et al. (2000b) assessed the contribution of the Hereford breed in the same multibreed beef cattle herd and suggested higher levels of Hereford contributions in crossbreeding for the prevention of dystocia. In another investigation Hereford sires were used also on heifers of other breeds to decrease the incidence of dystocia (Tawonezvi et al., 1988).

The large differences in WW in favour of the Charolais are attributed to large positive breed additive effects as compared to the Hereford. In a number of investigations the additive effects of the Charolais were mostly positive for WW (Alenda et al., 1980; Dillard et al., 1980; Olson et al., 1993; Franke et al., 2001). The Hereford positive additive effects for WW of calves were reported by Schoeman et al. (1993), while negative estimates of breed additive effects were evident in some other investigations (Gregory et al., 1978; Alenda et al., 1980; MacNeil et al., 1982; Skrypzeck et al., 2000a).

Differences in BW and WW owing to different dam genotypes were also evident $(\mathrm{P} \leq 0.001)$. Least squares means of calves by dam genotype are presented in Table 4 . 
Table 4 Least squares means and standard errors for birth weight (BW) and weaning weight (WW) of calves by genotype of dam

\begin{tabular}{|c|c|c|c|}
\hline Dam genotype & $\mathrm{N}$ & BW(kg) \pm s.e. & WW $(\mathrm{kg}) \pm$ s.e. \\
\hline Angus (A) & 391 & $32.7 \pm 0.35^{\mathrm{a}}$ & $175.2 \pm 1.8^{\mathrm{a}}$ \\
\hline Bonsmara (B) & 295 & $35.0 \pm 0.37^{\mathrm{cd}}$ & $186.9 \pm 1.8^{\mathrm{d}}$ \\
\hline Hereford $(\mathrm{H})$ & 588 & $34.6 \pm 0.30^{\mathrm{c}}$ & $176.2 \pm 1.5^{\mathrm{a}}$ \\
\hline $1 / 2 \mathrm{~A}^{1} / 2 \mathrm{C}^{*}$ & 141 & $37.6 \pm 0.45^{\mathrm{f}}$ & $193.8 \pm 2.2^{\mathrm{e}}$ \\
\hline $1 / 2 \mathrm{H}^{1} 1 / 2 \mathrm{~A}$ & 614 & $33.9 \pm 0.31^{\mathrm{b}}$ & $179.7 \pm 1.5^{\mathrm{b}}$ \\
\hline $1 / 2 \mathrm{C}^{1} / 2 \mathrm{~B}$ & 45 & $37.7 \pm 0.75^{\text {fg }}$ & $196.7 \pm 3.7^{\text {ef }}$ \\
\hline $1 / 2 \mathrm{H}^{1} / 2 \mathrm{~B}$ & 54 & $34.7 \pm 0.68^{\text {bcd }}$ & $189.5 \pm 3.4^{\mathrm{de}}$ \\
\hline $1 / 2 \mathrm{H}^{1 / 2} \mathrm{C}$ & 101 & $36.6 \pm 0.51^{\text {ef }}$ & $187.7 \pm 2.5^{\mathrm{d}}$ \\
\hline $1 / 2 \mathrm{C}^{1} / 4 \mathrm{~A}^{1} / 4 \mathrm{H}$ & 175 & $35.9 \pm 0.44^{\mathrm{de}}$ & $185.2 \pm 2.2^{\mathrm{cd}}$ \\
\hline $3 / 4 \mathrm{C}^{1} / 8 \mathrm{~A}^{1 / 8 \mathrm{H}}$ & 49 & $38.3 \pm 0.76^{\mathrm{f}}$ & $205.7 \pm 3.8^{\mathrm{f}}$ \\
\hline $3 / 4 \mathrm{H}^{1} / 4 \mathrm{~A}$ & 55 & $35.9 \pm 0.68^{\text {cdeg }}$ & $177.8 \pm 3.4^{\mathrm{abc}}$ \\
\hline $3 / 4 \mathrm{H}^{1 / 4} \mathrm{C}$ & 27 & $37.1 \pm 0.94^{\mathrm{ef}}$ & $193.3 \pm 4.7^{\mathrm{de}}$ \\
\hline
\end{tabular}

At birth the progeny of straightbred Angus dams was smaller $(\mathrm{P}<0.05)$ than those of Hereford, Bonsmara and crossbred dams. Calves from Hereford and Bonsmara dams and their crosses $\left(1 / 2 \mathrm{H}^{1} / 2 \mathrm{~B}\right)$ did not differ $(\mathrm{P}>0.05)$. Differences in $\mathrm{BW}$ of calves were observed between Bonsmara and BonsmaraCharolais crossbred dams $(\mathrm{P}<0.05)$. Among the crossbred cows the $1 / 2 \mathrm{~A} 1 / 2 \mathrm{H}$ crossbreds produced calves with the lowest $\mathrm{BW}$ while the three-breed cross $3 / 4 \mathrm{C}^{1} / 8 \mathrm{~A}^{1} / 8 \mathrm{H}$ dams produced the highest $\mathrm{BW}(\mathrm{P}<0.05)$. There was a tendency for Charolais crossbred cows to produce calves of heavier BW than other crossbred and straightbred dams. Another noticeable feature in this study was that no differences $(\mathrm{P}>0.05)$ in $\mathrm{BW}$ of calves from $1 / 2 \mathrm{C}^{1} / 2 \mathrm{H}, 1 / 2 \mathrm{C}^{1} / 2 \mathrm{~A}$ and $1 / 2 \mathrm{C}^{1 / 2} \mathrm{~B}$ dams were found, but these crossbred cows had calves with heavier $(\mathrm{P}<0.05) \mathrm{BW}$ than those of Hereford, Angus and Bonsmara dams. It was also indicated by Dillard et al. (1980) that when the Charolais was the breed of dam, heterosis values were larger than when the Charolais was the breed of sire for BW and WW.

In general, the absence of any difference in BW of calves for the majority of the crossbred dams may confirm the suggestions of MacDonald \& Turner (1972), Alenda et al. (1980) and McElhenney et al. (1986) that the influence of maternal heterosis on BW is either non-existing or negligible. The maternal effect of Charolais on BW was furthermore negative in the studies of Alenda et al. (1980), which may have contributed to such unexpected results. Likewise, the maternal effects of Hereford were also reported to be negative in the investigations of Gregory et al. (1978) and Skrypzeck et al. (2000a). The Angus maternal effect estimated for BW by Gregory et al. (1978) was negative while it was positive in the studies by Dillard et al. (1980).

Bonsmara dams weaned heavier $(\mathrm{P}<0.05)$ calves than both Hereford and Angus dams. Calves of crossbred dams were on average $5.7 \%$ heavier at weaning than calves of the straightbred dams. Among the crossbred dams, those with high Charolais proportions $\left(1 / 2 \mathrm{C}^{1 / 2} \mathrm{~B}\right.$ and $\left.3 / 4 \mathrm{C}^{1} / 8 \mathrm{~A}^{1 / 8} \mathrm{H}\right)$ weaned the heaviest calves. Among the dams evaluated for WW, Angus and Hereford dams produced the lowest WW. Dams of $1 / 2 \mathrm{~A}^{1} / 2 \mathrm{H}$ produced slightly heavier $(\mathrm{P}<0.05)$ calves than the parent breeds, while higher levels of Hereford $\left(3 / 4 \mathrm{H}^{1 / 4} / 4\right)$ in backcross dams did not differ from the parent breeds. Among the two-breed crosses involving Charolais, the $1 / 2 \mathrm{C}^{1} / 2 \mathrm{~A}$ and $1 / 2 \mathrm{C}^{1 / 2} \mathrm{~B}$ were superior to the $1 / 2 \mathrm{C}^{1 / 2} \mathrm{H}$ dams. Even though reciprocal crosses and some backcrosses were not available, which makes the dataset unsuitable for the estimation of dominance effects, it is possible to hypothesize on the maternal heterosis of WW from the observed means. The difference between mid-parent value and observed mean was calculated to be $4 \mathrm{~kg}$ for the $1 / 2 \mathrm{~A} 1 / 2 \mathrm{H}$ crosses. Likewise, the difference between mid-parent value and $1 / 2 \mathrm{~B}^{1} / 2 \mathrm{H}$ value was $8 \mathrm{~kg}$. The crosses were thus able to sustain WW of calves above the mid-parent value of their respective straightbreds. Therefore, maternal heterosis exists and validates the value of the crossbred dams in producing heavier WW.

In almost all comparable studies, the direct maternal effects of Hereford for WW were strongly negative (Alenda et al., 1980; Schoeman et al., 1993; Skrypzeck et al., 2000a; Franke et al., 2001). This large negative Hereford maternal effect considerably overrides the positive breed additive effect of the Hereford (Schoeman et al., 1993). The lower WW attained by calves of the Angus and Hereford dams compared to others dams probably substantiate the conclusion of Dillard et al., (1980) that Angus and 
Hereford dams do not provide enough milk and maternal ability to maximize growth in Charolais crossbred calves. Jenkins \& Ferrell (1992) also reported low milk producing ability of Hereford compared to Angus and Charolais cows. The Hereford and the majority of Hereford crossbred dams produced calves with noticeably lower WW's than other breeds in this study, and also in other studies.

\section{Conclusion}

Differences between Charolais and Hereford sires mated to the same dam genotypes may reflect differences in direct effects and individual heterotic effects exhibited in the crossbred calves. The Charolais sired calves were heavier than the Hereford sired calves for both BW and WW. In the light of this study the choice of sire breed should be made to complement those characteristics that are weak in other breeds by additive means and through exploitation of heterosis. To reduce the possibilities of dystocia, sire breed effects on BW should be thoroughly evaluated in different crossbreeding systems.

The performance of crossbred dams are encouraging, and with understanding of their better performance as crossbreds, use of crossbred dams for the improvement of weaning performance is advocated depending on effective breed combination to utilize additive and non-additive genetic effects. In several investigations the maternal effects of Hereford were largely negative, hence, high levels of Hereford in composite or crossbred dams do not seem to be of any advantage in this herd. However, inclusion of Charolais genes in these crossbreeding programmes improved the performance of crossbred cows which may be associated with improved milking abilities of the crossbred dam.

\section{References}

Alenda, R., Martin, T.G., Lasley, J.F. \& Ellersieck, M.R., 1980. Estimation of genetic and maternal effects in crossbred cattle of Angus, Charolais and Hereford parentage. I. Birth and weaning weights. J. Anim. Sci. 50, 226-234.

Bourdon, R.M., 2000. Understanding animal breeding. $2^{\text {nd }}$ ed. Prentice Hall, Inc. New Jersey. 538 pp.

Dillard, E.U., Rodriguez, O. \& Robison, O.W., 1980. Estimation of additive and non-additive direct and maternal genetic effects from crossbreeding beef cattle. J. Anim. Sci. 50, 653-663.

Franke, D.E., Habet, O., Tawah, L.C., Williams, A.R. \& DeRouen, S.M., 2001. Direct and maternal genetic effects on birth and weaning traits in multibreed cattle data and predicted performance of breed crosses. J. Anim. Sci. 79, 1713-1722.

Gregory, K.E., Cundiff, L.V., Kock, R.M., Laster, D.B. \& Smith, G.M., 1978. Heterosis and breed maternal and transmitted effects in beef cattle. I. Pre-weaning traits. J. Anim. Sci. 47, 1031-1041.

Harwin, G.O., 1989. Strategies for beef production in South Africa. A selection of lectures. Stock Owners Co-operative Ltd, South Africa.

Jenkins, T.G. \& Ferrell, C.L., 1992. Lactation characteristics of nine breeds of cattle fed various quantities of dietary energy. J. Anim. Sci. 70, 1652-1660.

Laster, D.B., Glimp, H.A., Cundiff, L.V. \& Gregory, K.E., 1973. Factors affecting dystocia and the effect of dystocia on subsequent reproduction in beef cattle. J. Anim. Sci. 36, 695-705.

Long, C.R., 1980. Crossbreeding for beef production: Experimental results. J. Anim. Sci. 51, 1197-1223.

MacNeil, M.D., Dinkel, C.A. \& Van Vleck, L.D., 1982. Individual and maternal additive and heterotic effects on 205-day weight in beef cattle. J. Anim. Sci. 54, 951-956.

McDonald, R.P. \& Turner, J.W., 1972. Estimation of maternal heterosis in pre-weaning traits of beef cattle. J. Anim. Sci. 35, 1146-1154.

McElhenney, W.H., Long, C.R., Baker, J.F. \& Cartwright, T.C., 1986. Production characters of first generation cows of a five-breed diallel: Reproduction of mature cows and pre-weaning performance of calves by two third-breed sires. J. Anim. Sci. 63, 59-67.

Newman, S., MacNeil, M.D., Reynolds, W.L., Knapp, B.W. \& Urick, J.J., 1993. Fixed effects in the formation of a composite line of beef cattle: II. Pre- and post-weaning growth and carcass composition. J. Anim. Sci. 71, 2033-2039.

Olson, T.A., Peacock, F.M. \& Koger, M., 1993. Reproductive and maternal performance of rotational, threebreed and inter se crossbred cows in Florida. J. Anim. Sci. 71, 2322-2329.

Pahnish, O.F., Brinks, J.S., Urick, J.J., Knapp, B.W. \& Riley, T.M., 1969. Results from crossing beef x beef and beef $\mathrm{x}$ dairy breeds: calf performance to weaning. J. Anim. Sci. 28, 291-299. 
Paterson, A.G., Venter, H.A.W. \& Harwin, G.O., 1980. Pre-weaning growth of British, Bos indicus, Charolais and dual-purpose type cattle under intensive pasture conditions. S. Afr. J. Anim. Sci. 10, 135-142.

SAS, 1996. Statistical Analysis System user's Guide (Version 6). SAS Institute Inc., Cary, N.C.

Schoeman, S.J. \& Jordaan, G.F., 1999. Multitrait estimation of direct and maternal (co)variances for growth and efficiency traits in a multibreed beef cattle herd. S. Afr. J. Anim. Sci. 29, 124-136.

Schoeman, S.J., Van Zyl, J.G.E. \& de Wet, R., 1993. Direct and maternal additive and heterotic effects in crossbreeding Hereford, Simmentaler and Afrikaner cattle. S. Afr. J. Anim. Sci. 23, 61-66.

Skrypzeck, H., Schoeman, S.J., Jordaan, G.F. \& Neser, F.W.C., 2000a. Estimates of crossbreeding parameters in a multibreed beef cattle crossbreeding project. S. Afr. J. Anim. Sci. 30, 193-203.

Skrypzeck, H., Schoeman, S.J., Jordaan, G.F. \& Neser, F.W.C., 2000b. Pre-weaning growth traits of the Hereford breed in a multibreed composite beef cattle population. S. Afr. J. Anim. Sci. 30, 220-229.

Smith, G.M., Laster, D.B. \& Gregory, K.E., 1976. Characterization of biological types of cattle. I. Dystocia and pre-weaning growth. J. Anim. Sci. 43, 27-36.

Tawonezvi, H.P.R., Ward, H.K., Trail, J.C.M. \& Light, D., 1988. Evaluation of beef breeds for rangeland weaner production in Zimbabwe. I. Productivity of purebred cows. Anim. Prod. 47, 351-359. 